\title{
UJI AKTIVITAS ANTIOKSIDAN EKSTRAK ETANOL DAUN BAWANG MEKAH (Eleutherine americana Merr.) TERHADAP GAMBARAN HISTOPATOLOGI PARU TIKUS (Rattus norvegicus) WISTAR JANTAN PASCA PAPARAN ASAP ROKOK
}

\author{
Hafidzah Ramadhaniyah Al Idrus ${ }^{1, *)}$, Iswahyudi ${ }^{2}$, Sri Wahdaningsih ${ }^{3}$ \\ 1. Program Studi Farmasi, Fakultas Kedokteran, Universitas Tanjungpura \\ 2. Bagian Kimia Farmasi, Fakultas Kedokteran, Universitas Tanjungpura \\ ${ }^{3}$ Bagian Biologi Farmasi, Fakultas Kedokteran, Universitas Tanjungpura
}

\begin{abstract}
Exposure to cigarette smoke is one of the exogenous free radicals. Exposure to cigarette smoke is associated with lung inflammation, oxidative stress and lipid peroxidation. Compounds that can inhibit the oxidation reaction by binding free radicals known as antioxidants. Eleutherine americana Merr. leaves has an antioxidant activity in invitro study. The aim of this work was to study E.americana leaves as a natural antioxidant that reduce the level of lung damage from exposure to cigarette smoke in male wistar rats and study effective dose of E.americana leaves to reduce the level of lung damage. The leaves of E.americana extracted by maceration method for 6 days using ethanol 70\%. Rats were divided into six groups of four animals each : exposed to ambient air (GroupA), exposed to cigarette smoke (Group B), exposed to cigarette smoke and treated with ethanol extract of E.americana leaves at dose $45 \mathrm{mg} / \mathrm{kg} \mathrm{bw}, 90 \mathrm{mg} / \mathrm{kg} \mathrm{bw}, 180 \mathrm{mg} / \mathrm{kg}$ bw (Group C,D,E), exposed to cigarette smoke and treated with vitamin $E$ dose $18 \mathrm{mg} / \mathrm{kg}$ bb(Group F). All rats were treated for 14 days using 3 cigarettes non filtered each day by using a smoking chamber. After 14 days rats were killed. Right lungs were removed for histopathology. The results showed that dose $45 \mathrm{mg} / \mathrm{kg} \mathrm{bw}, 90 \mathrm{mg} / \mathrm{kg} \mathrm{bw}, 180 \mathrm{mg} / \mathrm{kg}$ bw can reduce the level of lung damage to the enlarge of alveolar, thickening of the alveolar wall and inflammatory cell infiltration. Dose $180 \mathrm{mg} / \mathrm{kg} b \mathrm{w}$ as an effective dose to reduce the level of lung damage that compare to normal control.
\end{abstract}

Keywords : Antioxidant, Eleutherine americana, Lung histopathology, Cigarette smoke

\section{PENDAHULUAN}

\section{Latar Belakang}

Penggunaan rokok didunia semakin meningkat jumlahnya. Sebanyak $32.9 \%$ penggunaan rokok pada pria dan $18.4 \%$ penggunaan rokok pada wanita. Sekitar $60 \%$ pria dan $4,5 \%$ wanita di Indonesia adalah perokok. Tingginya jumlah perokok aktif berbanding lurus dengan jumlah perokok pasif yang terpapar asap rokok orang lain (second hand smoke) ${ }^{1}$.

Rokok mengandung lebih dari 4.000 zat berbahaya. Radikal bebas yang dihasilkan dari asap rokok mengakibatkan terjadinya penebalan pada dinding alveolus, pelebaran lumen alveolus dan peradangan pada alveoulus yang ditandai dengan meningkatnya jumlah leukosit dan alveolar makrofag ${ }^{2,3}$.

Senyawa yang dapat menghambat reaksi oksidasi dengan cara mengikat radikal dan molekul yang sangat reaktif, sehingga dapat menghambat kerusakan sel disebut sebagai antioksidan. Beberapa penelitian antioksidan yang pernah dilakukan menunjukkan bahwa beberapa tanaman seperti teh dan wortel memiliki aktivitas antioksidan dengan mengurangi kerusakan paru-paru tikus yang terpapar asap rokok ${ }^{2-4}$.
Salah satu jenis tanaman yang memilki potensi sebagai antioksidan yaitu tanaman bawang mekah (Eleutherine americana) yang dapat dikenal dengan nama bawang dayak, termasuk dalam famili Iridaceae dan berasal dari Amerika Tropis. Bawang mekah memiliki kandungan berupa polifenol, alkaloid, saponin, fenolik, dan flavonoid. Masyarakat di berbagai daerah di Kalimantan Barat umumnya menggunakan bagian umbi bawang mekah dalam pengobatan tumor secara tradisional. Umbi bawang mekah digunakan dengan cara dibuat dalam bentuk rebusan dan diminum, sedangkan bagian daunnya jarang dimanfaatkan ${ }^{5-6,10}$.

Beberapa penelitian yang pernah dilakukan terhadap tanaman bawang mekah memberikan hasil bahwa bulbus bawang mekah mempunyai aktivitas sebagai antibakteri dan sebagai antioksidan dengan $\mathrm{IC}_{50}$ sebesar $25,3339 \mu \mathrm{g} / \mathrm{mL}$. Penelitian aktivitas antioksidan ekstrak etanol 70\% daun bawang mekah menggunakan metode DPPH memiliki efek peredaman radikal bebas dengan nilai $\mathrm{IC}_{50}$ sebesar $31,97437 \mu \mathrm{g} / \mathrm{mL}^{7-10}$.

Penelitian diatas menjadi dasar dilakukannya pengujian aktivitas antioksidan dari ekstrak etanol daun bawang mekah secara in vivo pada tikus jantan 
yang terpapar asap rokok. Pengujian ini dilakukan dengan mengukur derajat kerusakan histopatologis paru-paru tikus wistar jantan yang terpapar asap rokok setelah pemberian ekstrak etanol $70 \%$ daun bawang mekah. Pengamatan histopatologi paru yang dilakukan meliputi pengamatan lebar lumen alveolus, pelebaran dinding alveolus dan infiltrasi sel radang. Hasil dari pengamatan ini akan dilakukan penilaian dengan diberi skor berdasarkan tingkat kerusakan masing-masing parameter.

\section{METODOLOGI}

A. Alat

Alat yang digunakan pada penelitian ini adalah timbangan analitik (Precisa), blender simplisia (IlinQi FZ-10), waterbath (Memmert WNB 22), oven (Memmert UP400), desikator, peralatan bedah, smoking chamber berukuran 38,5 x 28,5 x 22,5 cm, mikroskop (Zeiss Primo Star $\left.{ }^{\circledR}\right)$.

\section{B. Bahan}

Bahan yang digunakan pada penelitian ini adalah daun bawang mekah, etanol 70\%, etanol p.a, serbuk magnesium (Merck®), larutan $\mathrm{HCl} 2 \mathrm{~N}$, larutan $\mathrm{HCL}$ pekat, larutan $\mathrm{FeCl} 31 \%$, pereaksi Dragendorff, pereaksi Meyer, perekasi Wagner, larutan $\mathrm{H} 2 \mathrm{SO} 4$ 2N, larutan $\mathrm{H} 2 \mathrm{SO} 4$ pekat, asam asetat glasial, vitamin E, Carboxy Methyl Cellulose (CMC), aquades, aluminium foil, kertas saring.

\section{Hewan Uji}

Hewan uji yang digunakan dalam penelitian ini adalah tikus putih (Rattus norvegicus) galur wistar jantan. Sampel diperoleh secara acak yang memenuhi kriteria inklusi yaitu tikus putih wistar jantan, umur 2 - 3 bulan, berat badan 100- 200 gram, dan tidak cacat secara anatomi. Sedangkan kriteria eksklusinya adalah pada masa adaptasi tikus yang tampak sakit secara fisiologis dan terdapat penurunan berat badan yang drastis.

\section{Tahap Penelitian}

\section{Pengambilan dan Pengolahan Sampel}

Daun bawang mekah dipanen dari kebun di di Jalan Arteri Supadio, Desa Limbung, Kecamatan Sungai Raya, Kabupaten Kubu Raya, Kalimantan Barat. Daun yang diambil berumur 3-4 bulan. Daun bawang mekah yang telah dikumpulkan, dicuci dan dirajang halus. Kemudian daun dikeringkan dibawah sinar matahari secara tidak langsung, daun yang telah kering disimpan dalam wadah kering dan tertutup rapat.

\section{Pembuatan Ekstrak}

Metode ekstraksi yang digunakan dalam penelitian ini adalah ekstraksi maserasi. Simplisia daun bawang mekah sebanyak $200 \mathrm{~g}$ direndam dengan pelarut etanol $70 \%$ dalam bejana selama $6 \times 24$ jam, setiap 1x24 jam pelarut diganti dan dilakukan pengadukan sesering mungkin. Kemudian filtrat disaring dan dipekatkan dengan rotary evaporator dan waterbath hingga diperoleh ekstrak kental.

\section{Penetapan Susut Pengeringan}

Penetapan susut pengeringan adalah pengukuran sisa zat setelah pengeringan pada temperatur $105^{\circ} \mathrm{C}$ selama 30 menit atau sampai berat konstan yaitu tidak terjadi lagi perubahan bobot (tidak lebih dari 5\%). Ekstrak ditimbang sebanyak 2,9072 gram ; 2,04 gram ; 2,1514 gram, masingmasing dimasukkan ke dalam botol timbang dangkal bertutup yang sebelumnya telah dipanaskan pada suhu $105^{\circ} \mathrm{C}$ selama 30 menit dan telah ditara. Sebelum ditimbang ekstrak diratakan dalam botol timbang, dengan menggoyangkan botol. Kemudian dimasukkan kedalam ruang pengering, buka tutupnya. Keringkan pada suhu $105^{\circ} \mathrm{C}$ hingga bobot tetap. Sebelum setiap pengeringan,biarkan botol dalam keadaan tertutup mendingin dalam desikator hingga suhu kamar ${ }^{11}$.

\section{Skrining Fitokimia Pemeriksaan Alkaloid}

Ekstrak ditambahkan dengan 0,5-1 $\mathrm{mL}$ asam sulfat $2 \mathrm{~N}$ dan dikocok sampai terbentuk dua lapisan. Lapisan asam (atas) dipipet dan ditambahkan kloroform dan amonia. Kemudian dimasukkan ke dalam tiga buah tabung reaksi. Tabung reaksi pertama ditambahkan dua tetes pereaksi Mayer. Tabung reaksi kedua ditambahkan dua tetes pereaksi Dragendorff. Tabung reaksi ketiga ditambahkan dua tetes pereaksi Wagner. Adanya senyawa alkaloid ditandai dengan terbentuknya endapan putih pada tabung reaksi pertama dan timbulnya endapan berwarna coklat kemerahan pada tabung reaksi kedua dan ketiga ${ }^{12}$.

\section{Pemeriksaan Flavonoid}

Larutan ekstrak sebanyak $2 \mathrm{ml}$ ditambah dengan $0,5 \mathrm{~mL}$ asam klorida pekat ( $\mathrm{HCl}$ pekat) dan beberapa miligram serbuk logam $\mathrm{Mg}$. Adanya flavonoid ditandai dengan warna merah, orange dan hijau tergantung pada struktur flavonoid yang terkandung dalam sampel ${ }^{12}$.

\section{Pemeriksaan Saponin}

Ekstrak sebanyak $50 \mathrm{mg}$ dimasukkan ke dalam tabung reaksi, lalu ditambahkan dengan air $20 \mathrm{~mL}$ 
dan dikocok dengan kuat selama 15 menit. Hasil positif ditunjukkan dengan terbentuknya busa dengan tinggi $2 \mathrm{~cm}^{12}$.

\section{Pemeriksaan Triterpenoid dan Steroid}

Larutan ekstrak sebanyak $1 \mathrm{ml}$ ditambahkan dengan 3 tetes $\mathrm{CH}_{3} \mathrm{COOH}$ asetat dan 1 tetes larutan $\mathrm{H}_{2} \mathrm{SO}_{4}$ pekat. Warna berubah menjadi merah, menunjukkan adanya kelompok senyawa triterpenoid. Warna biru menunjukkan adanya steroid 12 .

\section{Pemeriksaan Fenol}

Larutan ekstrak diteteskan di atas pelat tetes dan ditambah larutan $\mathrm{FeCl}_{3} 1 \%$. Hasil positif yaitu timbul warna biru kehitaman ${ }^{12}$.

\section{Pemeriksaan Tanin}

Ekstrak ditambahkan dengan Gelatin 1\% dan $\mathrm{NaCl} 10 \%$. Hasil positif yaitu timbul endapan putih 12

\section{Pengujian Aktivitas Antiokisdan Perlakuan Hewan}

Seluruh tikus Wistar diadaptasikan selama tujuh hari. Hari kedelapan tikus diberi paparan asap rokok setiap harinya selama 14 hari. Proses pemaparan dilakukan dalam smoking chamber. Satu jam setelah pemaparan asap rokok, tikus diberi ekstrak etanol sesuai variasi dosis. Seluruh hewan percobaan diadaptasikan selama tujuh hari. Tikus yang diadaptasi akan diberikan makan dan minum secukupnya. Kemudian hewan percobaan dipilih secara acak dibagi menjadi enam kelompok. Kelompok A merupakan kelompok normal tanpa paparan asap rokok dan hanya diberi suspensi CMC $1 \%$ Kelompok $\mathrm{B}$ adalah kelompok kontrol negatif yang hanya diberikan paparan asap rokok dan suspensi CMC 1\%. Kelompok C, D dan E adalah kelompok perlakuan yang diberikan paparan asap rokok dan ektrak etanol daun bawang mekah dengan dosis 45, 90 dan $180 \mathrm{mg} / \mathrm{kg}$ BB. Kelompok F adalah kelompok kontrol postif yang diberikan paparan asap rokok dan vitamin $\mathrm{E}$ dosis $18 \mathrm{mg} / \mathrm{kg}$ BB.

\section{Pengamatan Histopalogi Paru}

Preparat diamati dibawah mikroskop dalam 5 lapangan pandang, yaitu pada keempat sudut dan bagian tengah preparat, dengan perbesaran 100x dan 400x. Sasaran yang dibaca adalah persentase pelebaran lumen alveolus, penebalan dinding alveolus, infiltrasi sel radang dengan kriteria sebagai berikut $^{3,13}$ :

a. Skoring pelebaran lumen dan penebalan dinding
SKOR 0 : tidak ada perubahan histologis

SKOR 1 : terjadi kerusakan pada kurang dari sepertiga lapang pandang

SKOR2 : terjadi kerusakan pada sepertiga hingga duapertiga lapang pandang

SKOR 3 : terjadi kerusakan pada lebih dari duapertiga lapang pandang

b. Skoring infiltrasi sel radang

SKOR 0 : tidak ada perubahan histologis

SKOR 1 : infiltrasi sel radang pada kurang dari sepertiga lapang pandang

SKOR 2 : infiltrasi sel radang kerusakan pada sepertiga hingga duapertiga lapang pandang

SKOR 3 : infiltrasi sel radang pada lebih dari duapertiga lapang pandang

Nilai skor dari ketiga paramter kemudian dirataratakan, hasil rata-rata tersebut dikali $100 \%$ untuk mendapatkan nilai persen derajat kerusakannya. Kemudian hasil presentase derajat kerusakan paru yang telah didapat diklasifikasikan berdasarkan tingkat kerusakan paru yang terdiri dari ${ }^{14}$ :

Tabel 1. Penentuan Tingkat Kerusakan Paru

\begin{tabular}{|c|c|c|}
\hline No & $\begin{array}{c}\text { Presentase } \\
\text { Derajat } \\
\text { Kerusakan }\end{array}$ & Tingkat Kerusakan \\
\hline 1. & $0 \%$ & $\begin{array}{c}\text { Tidak terjadi } \\
\text { kerusakan }\end{array}$ \\
\hline 2. & $<30 \%$ & Kerusakan Ringan \\
\hline 3. & $30-60 \%$ & Kerusakan Sedang \\
\hline 4. & $>60 \%$ & Kerusakan Berat \\
\hline
\end{tabular}

\section{Analisis Data}

Data kuantitatif yang diperoleh dianalisis dengan program analisis statistik. Data kerusakan paru diolah dengan uji Shapiro Wilk untuk uji normalitas data. Uji homogenitas dilakukan menggunakan uji Levene Test. Data yang didapat tidak terdistribusi dan tidak homogen, maka selanjutnya data dianalisis menggunakan uji nonparametrik yaitu uji Kruskal-Wallis untuk melihat ada atau tidaknya perbedaan pada kelompok percobaan. Jika terdapat perbedaan, maka minimum harus terdapat satu kelompok yang berbeda dari kelompok lain. Kemudian dilanjutkan dengan melakukan analisis post hoc untuk mengetahui pasangan kelompok mana yang mempunyai perbedaan signifikan dari semua kelompok dengan menggunakan uji Mann Whitney. 


\section{HASIL DAN PEMBAHASAN}

\section{Pengambilan dan Pengolahan Sampel}

Sampel tanaman yang berupa daun diambil dari kebun bawang mekah yang berada di Jalan Arteri Supadio, Desa Limbung, Kecamatan Sungai Raya, Kabupaten Kubu Raya, Kalimantan Barat. Pengambilan sampel dilakukan pada bulan November 2013. Daun yang diambil berumur 3-4 bulan, hal ini dikarenakan pada umur 3-4 bulan, daun bawang mekah telah memiliki kandungan senyawa aktif yang optimal. Bagian yang diambil adalah bagian daun yang bebas hama dan kerusakan. Daun bawang mekah yang telah dikumpulkan, dicuci dan dirajang halus. Kemudian daun dikeringkan dibawah sinar matahari secara tidak langsung, daun yang telah kering disimpan dalam wadah kering dan tertutup rapat.

\section{Ektraksi}

Maserasi dilakukan dengan merendam 200 gram simplisia daun bawang mekah dalam etanol $70 \%$ sebanyak 1 liter. Maserasi dilakukan selama 6 hari sehingga total pelarut yang digunakan adalah 6 liter. Setelah dilakukan proses maserasi, maserat yang diperoleh dievaporasi menggunakan evaporator pada suhu $60{ }^{\circ} \mathrm{C}$ dengan kecepatan $100 \mathrm{rpm}$. Hasil ekstrak yang telah dievaporasi kemudian dipekatkan menggunakan waterbath dengan suhu $60^{\circ} \mathrm{C}$. Hasil ekstrak yang diperoleh adalah 35,7 gram dengan nilai rendemen $17,85 \%$.

\section{Penetapan Susut Pengeringan}

Hasil pemeriksaan penetapan susut pengeringan untuk ekstrak etanol daun bawang mekah yang diperoleh yaitu 19,55\%. Ekstrak dengan persentase $19,55 \%$ termasuk dalam rentang ekstrak kental yaitu 5-30\% ${ }^{11,15}$.

\section{Skrining Fitokimia}

Tabel 2. Hasil Skrining Fitokimia

\begin{tabular}{|c|c|c|}
\hline No & Perlakuan & Hasil \\
\hline 1 & Alkaloid & + \\
\hline 2 & Flavonoid & + \\
\hline 3 & Saponin & + \\
\hline 4 & Triterpenoid dan Steroid & + \\
\hline 5 & Tanin & - \\
\hline 6 & Fenolik & + \\
\hline
\end{tabular}

Keterangan: (+) positif : terdeteksi; (-) negatif: tidak terdeteksi.
Hasil yang diperoleh pada tabel 2, dapat dilihat bahwa pada ekstrak etanol $70 \%$ dari daun bawang mekah mengandung senyawa yang tergolong alkaloid, flavonoid, saponin, fenolik, steroid dan triterpenoid.

\section{Pengujian Aktivitas Antioksidan Perlakuan Hewan Uji}

Pengujian aktivitas antioksidan yang dilakukan secara in vivo menggunakan hewan uji tikus putih jantan galur wistar. Penggunaan tikus putih sebagai hewan uji dikarenakan tikus putih telah dikenal sebagai model hewan percobaan yang baik, mudah ditangani, dapat diperoleh dalam jumlah besar, dan memberi hasil nilai ulangan yang dapat dipercaya. Pemilihan galur wistar dikarenakan tikus wistar mempunyai kemampuan metabolisme yang relatif cepat sehingga lebih sensitif bila digunakan dalam penelitian yang berhubungan dengan metabolisme tubuh. Pemilihan tikus putih jantan dikarenakan tikus jantan tidak memiliki fase estrus sehingga kondisi biologis tubuh lebih stabil dibanding tikus betina ${ }^{16-18}$.

Hewan uji yang digunakan diadaptasikan selama 7 hari sebelum diberi perlakuan. Adaptasi dengan lingkungan laboratorium bertujuan agar hewan uji terbiasa dan tidak mengalami stress akibat lingkungan yang baru. Adaptasi dilakukan dengan memberikan makan dan minum kepada hewan uji. Perlakuan ini bertujuan untuk meningkatkan berat badan tikus hingga sesuai dengan berat badan yang diinginkan pada pengujian. Berat badan yang digunakan pada saat pengujian ialah berkisar antara 100-200 gram. Selain itu hewan uji juga diperhatikan kesehatannya. Hewan uji yang digunakan ialah hewan uji yang sehat dan tidak adanya kecacatan fisik seperti buta, berjalan tidak sejajar atau mengalami luka-luka. Hal ini bertujuan untuk menyeragamkan kondisi dari hewan uji sehingga akan meminimalisir kesalahan yang berasal dari hewan uji dan untuk memastikan hewan uji dalam kondisi sehat.

Setelah diadaptasi, hewan uji diberi perlakuan dengan dikondisikan seperti perokok pasif yang terpapar asap rokok. Jumlah rokok yang digunakan adalah tiga batang pada setiap kali pemaparan. Jumlah rokok pada tiap kali pemaparan didasarkan pada nilai LD50 nikotin pada tikus yaitu $50 \mathrm{mg} / \mathrm{kg}$ bb 19. Pemaparan asap rokok dilakukan saat pagi hari pada jam yang sama selama 14 hari pengamatan. Pemaparan dilakukan pada pagi hari dikarenakan tikus akan menjadi semakin agresif pada siang hari. Tikus yang agresif pada siang hari dikarenakan tikus termasuk hewan nokturnal yaitu hewan yang aktif pada malam hari dan akan tidur pada siang hari. 
Rokok dipaparkan secara akut selama 14 hari manggunakan smoking chamber. Paparan akut dipilih berdasarkan penelitian yan dilakukan oleh Khabour et al (2014) dan Van der Vaart et al (2004) menunjukkan asap rokok yang dipaparkan secara akut akan memberikan hasil yang sensitif untuk menyelidiki efek spesifik dari asap rokok pada stres oksidatif dan inflamasi, serta paparan akut sudah dapat menyebabkan terjadinya kerusakan elastisitas pada jaringan paru. Smoking chamber dilengkapi dengan ventilasi dan dua buah pompa udara ${ }^{20,21}$

Asap rokok yang dihirup akan masuk kedalam tubuh melalui saluran pernapasan. Paru berperan sebagai alat pernapasan utama pada sistem pernapasan. Sehingga ketika radikal bebas asap rokok masuk kedalam tubuh, maka organ yang terkena dampak secera langsung adalah paru. Dampak kerusakan paru akibat asap rokok dapat diamati dengan parameter berupa adanya pelebaran pada lumen alveolus, penebalan pada dinding alveolus dan infiltrasi sel radang. Mekanisme terjadinya kerusakan paru akibat asap rokok adalah tubuh akan merespon asap rokok sebagai antigen yang akan memicu keluarnya mediator inflamasi. Ketika jumlah radikal bebas yang masuk berlebihan dan tubuh tidak dapat mencegahnya maka akan terjadi kerusakan pada paru melalui mekanisme stres oksidatif. Stres oksidatif yang terjadi secera terus menerus mengakibatkan terjadinya penumpukan hasil kerusakan. Selanjutnya stres oksidatif menyebabkan peroksidasi lipid yang akan menimbulkan kerusakan sel dan inflamasi. Proses inflamasi akan mengaktifkan sel alveolar makrofag sebagai pertahanan pertama, aktivasi sel tersebut akan menyebabkan dilepaskannya faktor kemotatik neutrofil, seperti interleukin 8 dan leukotrien B4 yang merangsang neutrofil melepaskan protease yang dapat merusak jaringan ikat parenkim paru dengan menyebabkan terjadinya elastisitas berlebihan pada paru sehingga timbul kerusakan dinding alveolar dan hipersekresi mukus. Selain itu radikal bebas akan menyebabkan terjadinya inaktivasi $\alpha 1$-anti trypsin yang berperan sebagai anti protease Ketidakseimbangan antara protease dengan antiprotese yang terdapat pada jaringan alveolar menyebabkan degradasi jaringan paru 3,13,22-24. Pengamatan yang dilakukan pada hewan uji menujukkan adanya perubahan pada hewan uji sebelum dan sesudah diberi paparan asap rokok. Perubahan yang terjadi menunjukkan terjadinya stres pada hewan uji. Perubahan yang terjadi meliputi dehidrasi yang ditandai dengan hewan uji yang berkeringat, keaktifan hewan uji yang menurun, detak jantung yang lebih cepat, bunyi seperti mengi pada saat bernapas dan meningkatnya suhu tubuh hewan.

Hewan uji diberi perlakuan selama 14 hari, kemudian dilakukan pengorbanan atau terminasi hewan uji pada masing - masing perlakuan. Terminasi dilakukan dengan dislokasi servikalis tanpa dibius menggunakan kloroform, hal ini disebabkan kloroform dikhawatirkan dapat mempengaruhi hasil histopatologi pada paru tikus. Setelah dilakukan dislokasi tulang leher, hewan dibedah dan paru sebelah kanan. Digunakan paru sebelah kanan dikarenakan pada penelitian yang menggunakan inhalasi pada tikus, paru kanan akan menunjukkan hasil yang lebih baik, serta pada paru kanan memiliki jumlah lobus yang lebih banyak sehingga akan mempermudah dalam pengamatan paru ${ }^{25}$. Kemudian hewan paru diproses menjadi preparat histopatologi. Pembuatan preparat histopatologi paru dilakukan Laboratorium Patologi Anatomi RSUD Dr. Soedarso.

\section{Pengamatan Histopatologi Paru}

Pengamatan terhadap gambaran histopatologi paru digunakan untuk mengetahui pengaruh pemberian ekstrak etanol daun bawang mekah terhadap penurunan kerusakan paru akibat paparan asap rokok. Adapun penyiapan preparat dan pembacaan hasil histopatologi paru dibantu oleh ahli patologi dan anatomi. Parameter kerusakan paru yang dihitung skornya mencakup pelebaran lumen alveolus, penebalan dinding alveolus dan infiltrasi sel radang. Ketiga parameter tersebut merupakan kelainan patologi yang paling sering digunakan pada pengamatan preparat histopatologi paru.

Metode yang digunakan yaitu dengan pemberian skor (skoring) agar dapat mengukur sejauh mana kerusakan yang ditimbulkan maupun pemulihan yang terjadi berdasarkan keadaan sel dan jaringan. Pembacaan hasil preparat histopatologi paru diamati dengan cara blind test yaitu keseluruhan preparat yang sebelumnya sesuai dengan nama tiap kelompok diubah dengan diberi kode yang berbeda oleh orang lain yang tidak melakukan penelitian ini, kemudian preparat yang telah diberi kode tertentu tadi selanjutnya dilakukan pembacaan skoring derajat kerusakan paru. Cara perhitungan derajat kerusakan menggunakan metode kuadran.

\section{Analisis Hasil Histopatologi Paru}

Hasil histopatologi dianalisis berdasarkan parameter pelebaran lumen alveolus, penebalan dinding alveolus dan infiltrasi sel radang. Parameter derajat kerusakan pada pelebaran lumen alveolus menunjukkan terjadinya emfisema. Emfisema 
merupakan keadaan paru yang mempunyai kenaikan ukuran lebih dari normal pada rongga udara bagian distal sampai bronkhiolus terminal dan destruksi pada dinding alveoli. Hal Hal ini dapat terjadi karena asap rokok menginduksi sel epitel untuk memproduksi sitokin yang menstimulus pelepasan dan mengaktivasi pada neutrofil dan makrofag. Selain itu asap rokok menginaktivasi antiprotease. Proses ini akan menyebabkan ketidakseimbangan antara protease dan antiprotease yang akan menyebabkan degrdasi pada paru sehingga terjadi pelebaran pada lumen alveolus. Parameter kerusakan berupa infiltrasi sel radang ditimbulkan karena radikal bebas asap rokok memicu respon imun dengan adanya infiltrasi leukosit terutama neutrofil pada pembuluh darah paru dinding alveolus. Penumpukan sel radang pada dinding alveolus menyebabkan terjadinya penebalan pada struktur dinding alveolus. Adapun hasil skoring paru berdasarkan klasifikasi tingkat kerusakan terdapat pada tabel 3, adapun grafik presentase kerusakan paru dapat dilihat pada gambar 1, adapun gambaran perubahan histopatologi paru pada pelebaran lumen alveolus dapat dilihat pada gambar 2 , perubahan pada penebalan dinding dan infiltrasi sel radang dapat dilihat pada gambar 3 .

Tabel 3. Hasil Tingkat Kerusakan Paru

\begin{tabular}{|c|c|c|}
\hline Perlakuan & $\begin{array}{c}\text { Derajat } \\
\text { kerusakan } \\
\text { Mean } \pm \text { SD })\end{array}$ & $\begin{array}{c}\text { Klasifikasi } \\
\text { Tingkat } \\
\text { Kerusakan }\end{array}$ \\
\hline Normal & $40,150 \pm 3,101$ & Sedang \\
\hline Negatif & $91,450 \pm 0,404$ & Berat \\
\hline $\begin{array}{c}\text { Dosis } \\
45 \mathrm{mg} / \mathrm{kg} \\
\mathrm{bb}\end{array}$ & $76,850 \pm 9,489$ & Berat \\
\hline $\begin{array}{c}\text { Dosis } \\
90 \mathrm{mg} / \mathrm{kg} \\
\mathrm{bb}\end{array}$ & $65,350 \pm 4,689$ & Berat \\
\hline $\begin{array}{c}\text { Dosis } \\
180 \mathrm{mg} / \mathrm{kg} \\
\mathrm{bb}\end{array}$ & $50,175 \pm 7,349$ & Sedang \\
\hline $\begin{array}{c}\text { Vitamin E } \\
43,100 \pm 0,025\end{array}$ & Sedang \\
\hline
\end{tabular}

Hasil skoring paru berdasarkan klasifikasi tingkat kerusakan, terlihat kelompok yang memiliki kerusakan paling rendah adalah kelompok normal, namun pada kelompok normal terjadi kerusakan paru dengan tingkat kerusakan sedang. Terjadinya kerusakan pada kelompok normal dapat disebabakan karena adanya variabel luar yang tidak bisa dikendalikan, seperti kondisi psikologis tikus yang dipengaruhi oleh lingkungan sekitar, seperti lingkungan yang terlalu gaduh, pemberian perlakuan berulang kali, dan perkelahian antar tikus. Selain itu dalam kondisi normal, radikal bebas sudah terdapat di dalam tubuh. Radikal bebas jenis ini disebut endogenous free radical. Secara alami, tubuh juga telah mempunyai antioksidan sebagai inhibitor yang bekerja menghambat oksidasi dengan cara bereaksi dengan radikal bebas reaktif membentuk radikal bebas yang relatif stabil.

Hasil skoring derajat kerusakan paru paling tinggi terdapat pada kelompok perlakuan kontrol negatif yaitu 91,450. Hasil skoring kelompok negatif yang dibandingka dengan kelompok kontrol normal memiliki nilai perbedaan yang paling signifikan yaitu $\mathrm{p}=0,01(\mathrm{p}<0,05)$.

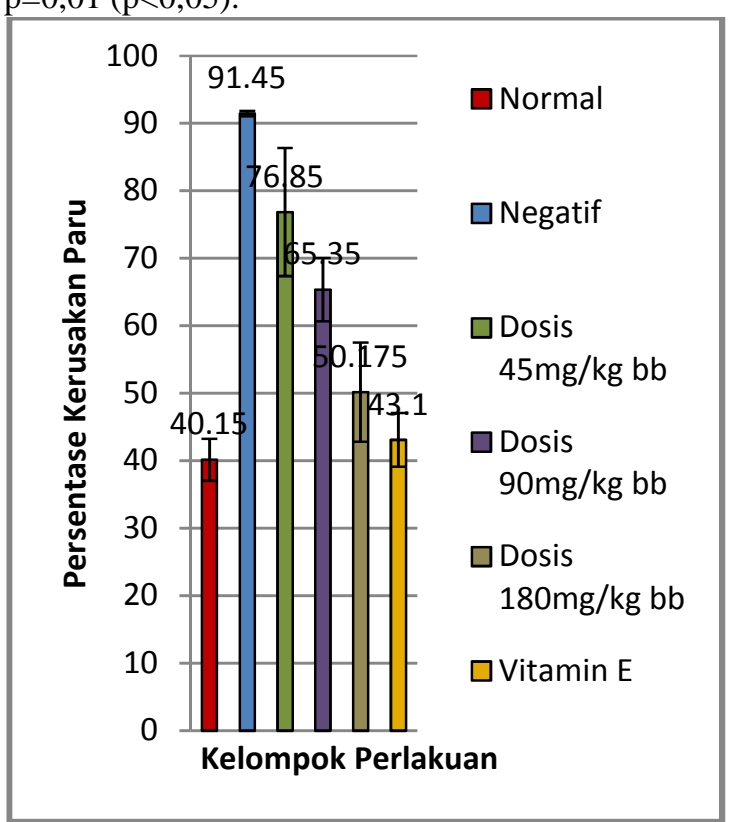

\section{Gambar 1. Grafik Presentase Kerusakan Paru}

Hal ini disebabkan pada kelompok kontrol normal, hewan uji tidak diberikan paparan asap rokok sedangkan pada kelompok kontrol negatif hanya diberikan asap rokok tanpa asupan antioksidan. Hasil ini sesuai dengan literatur yang ada bahwa radikal bebas yang berasal asap rokok dapat mengakibatkan terjadinya kerusakan pada paru melalui mekanisme asap rokok menyebabkan terjadinya stres oksidatif yang merusak alveolus paru. Oksidan yang terdapat dalam asap rokok menyebabkan peningkatan protease akibat aktivasi neutrofil dan defisiensi antiprotease. Antiprotease dihambat oleh radikal bebas sehingga membuat ketidakseimbangan antara radikal bebas dan antioksidan. 
Kelompok perlakuan dosis bertingkat esktrak etanol daun bawang mekah dianalisis dengan dibandingkan dengan kelompok kontrol negatif, hal ini bertujuan untuk mengetahui besarnya kemampuan penurunan derajat kerusakan paru oleh ekstrak. Analisis pada kelompok perlakuan yang diberikan dosis bertingkat ekstrak etanol daun bawang mekah yang terdiri dari dosis I $(45 \mathrm{mg} / \mathrm{kg} \mathrm{bb})$, dosis II $(90 \mathrm{mg} / \mathrm{kg} \mathrm{bb})$ dan dosis III $(180 \mathrm{mg} / \mathrm{kg} \mathrm{bb})$ dengan
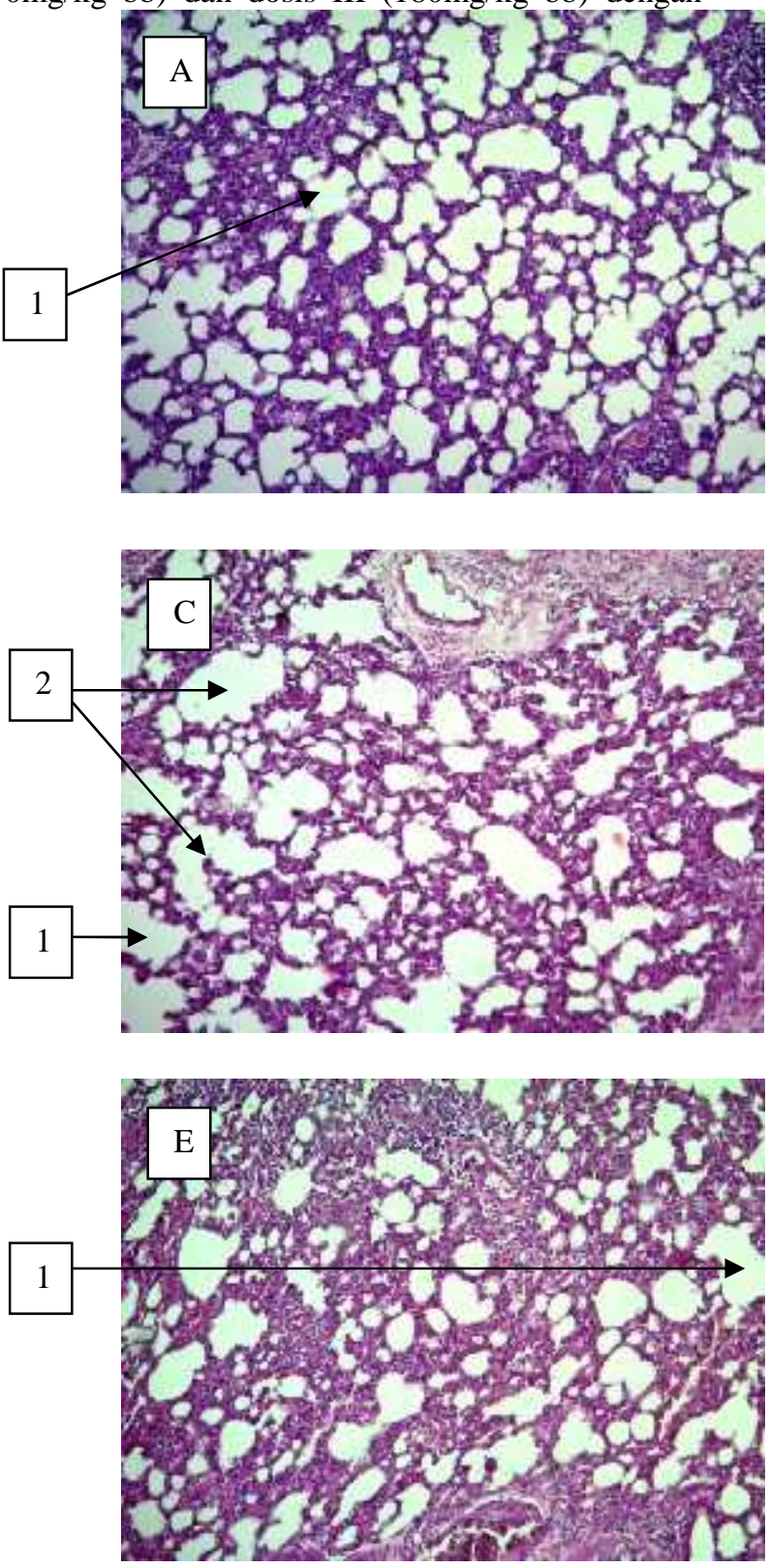

kelompok kontrol negatif menunjukkan adanya perbedaan yang signifikan antara kelompok perlakuan dosis dengan kelompok kontrol negatif dengan nilai signifikansi yaitu 0,019 $(\mathrm{p}<0,05)$. Hasil tersebut menunjukkan adanya penurunan kerusakan paru.
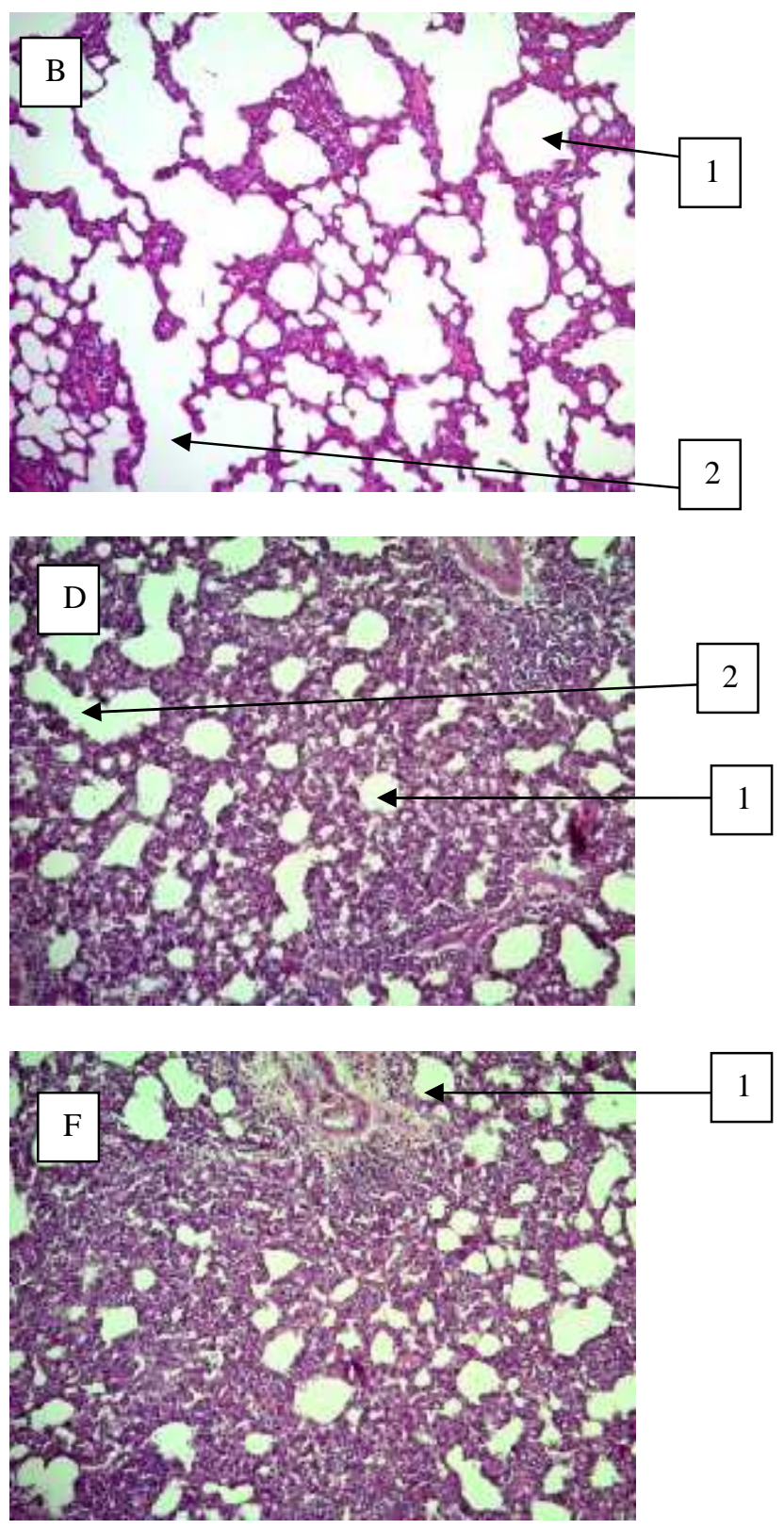

Gambar 2. Gambaran Parameter Pelebaran Lumen Alveolus : a. Kelompok Normal; b. Kelompok Kontrol (-); c. Kelompok Dosis 45mg/kg bb; d. Kelompok Dosis 90mg/kg bb; e. 
Kelompok Dosis 180mg/kg bb; f. Kelompok kontrol (+). Keterangan : (1). Lumen Alveolus Normal (2); Pelebaran Lumen Alveolus. Perbesaran 100x.
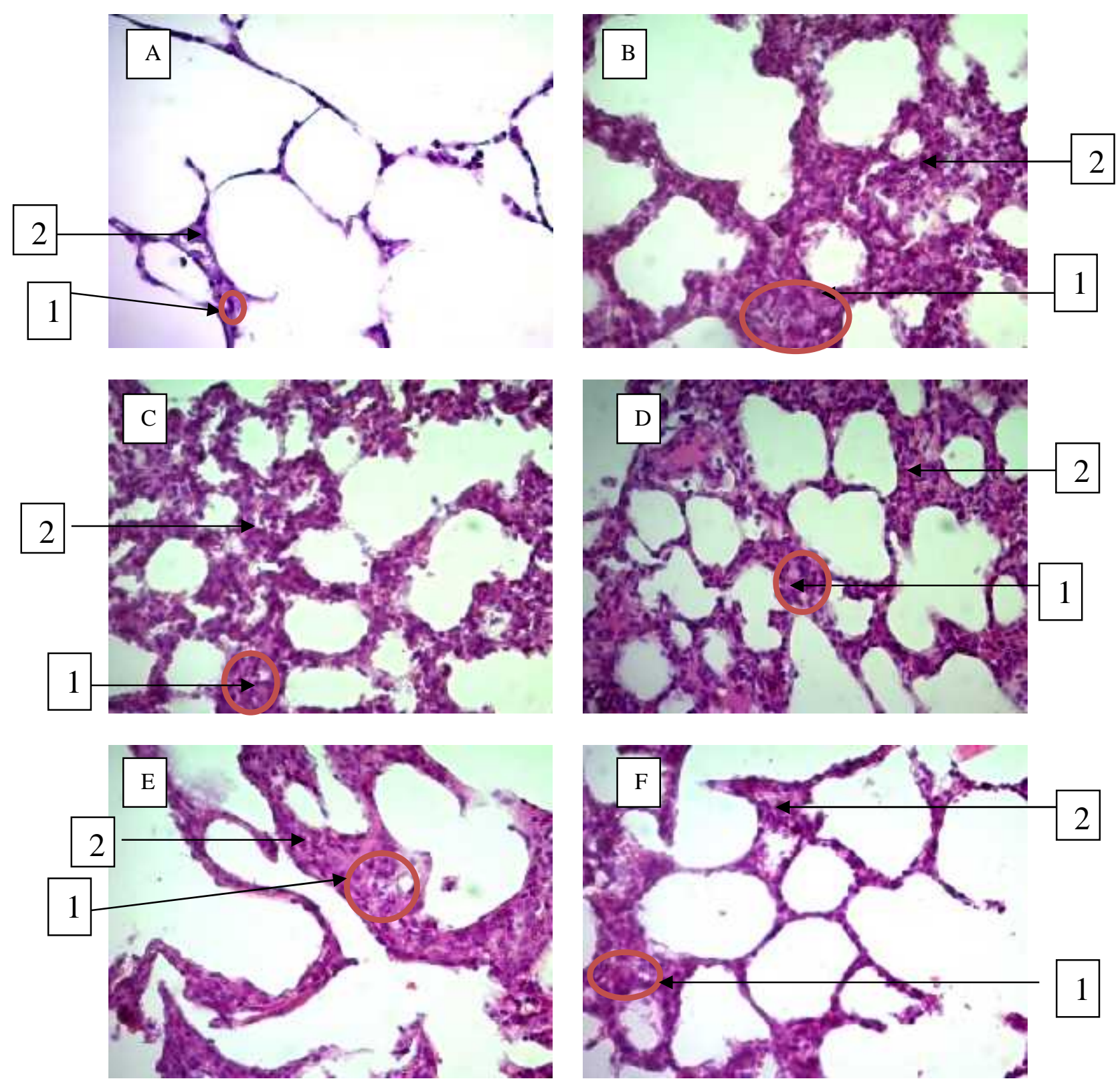

Gambar 3. Gambaran Penebalan Dinding Alveolus dan Infiltrasi Sel Radang : a. Kelompok Normal; b. Kelompok Kontrol (-); c. Kelompok Dosis 45mg/kg bb; d. Kelompok Dosis 90mg/kg bb; e. Kelompok Dosis 180mg/kg bb; f. Kelompok kontrol (+). Keterangan : (1). Penebalan dinding Alveolus; (2) infiltrasi sel radang. Perbesaran 400x. 
Penentuan dosis efektif pada ekstrak etanol daun bawang mekah dilakukan dengan membandingkan kelompok perlakuan dosis dengan kelompok kontrol normal. Hasil analisis antara kelompok perlakuan dosis dengan kelompok kontrol normal menunjukkan nilai yang berbeda signifikan ( $>>0,05)$. Kelompok perlakuan dosis yang memilki nilai signifikansi paling kecil dibandingkan kelompok dengan kelompok perlakuan dosis lainnya yaitu pada kelompok perlakuan dosis III. Kelompok perlakuan dosis ini memiliki tingkat kerusakan paling mendekati normal. Sehingga kelompok perlakuan dosis III merupakan kelompok dosis yang efektif dalam penurunan derajat kerusakan paru akibat paparan asap rokok. Selain itu Kelompok perlakuan dosis III yang dianalisis dengan kelompok kontrol positif menunjukkan penurunan tingkat kerusakan yang tidak signifikan yaitu $\mathrm{p}=0,386 \quad(\mathrm{p}>0,05)$. Sehingga dapat disimpulkan bahwa dosis III ekstrak etanol daun bawang mekah sama efektifnya dengan vitamin $\mathrm{E}$ untuk menurunkan derajat kerusakan paru akibat asap rokok.

Ekstrak etanol daun bawang mekah dapat menurunkan derajat kerusakan paru diduga karena mengandung beberapa senyawa seperti alkaloid, flavonoid, saponin, fenolik, steroid dan triterpenoid. Senyawa alkaloid dapat menurunkan derajat kerusakan paru diduga karena memilki peran sebagai antiprotease. Senyawa alkaloid berperan sebagai antiprotease dalam menghambat rhodesain and cathepsin L ${ }^{26}$. Senyawa flavonoid diduga memiliki aktivitas antioksidan untuk menurunkan derajat kerusakan paru dengan berperan dengan menghambat pelepasan pada sel-sel radang seperti alveolar makrofag dan neutrofil ${ }^{27}$. Saponin dapat berperan berperan sebagai antioksidan diduga karena memiliki peran sebagai inhibitor protease dalam menghambat pelepasan sitokin seperti TNF-alpha, IL-1beta, IL-2 dan interferon-gamma ${ }^{28}$. Senyawa fenolik dapat berperan sebagai antioksidan diduga karena dapat menghambat masuknya makrofag alveolar dan neutrofil ke dalam lumen alveolus ${ }^{3}$. Senyawa steroid dan triterpenoid dapat berperan sebagai antioksidan diduga karena dapat berperan sebagai inhibitor protease pada aktivitas tripsin ${ }^{29}$.

\section{KESIMPULAN}

Berdasarkan hasil penelitian aktivitas antioksidan ekstrak etanol daun bawang mekah terhadap gambaran histopatologi paru tikus (Rattus norvegicus) wistar jantan yang diberi asap rokok dapat disimpulkan bahwa ekstrak etanol daun bawang mekah dapat menurunkan derajat kerusakan paru-paru akibat paparan asap rokok pada hewan uji tikus jantan galur wistar. Dosis efektif ekstrak etanol daun bawang mekah yang dapat menurunkan derajat kerusakan paru-paru akibat paparan asap rokok pada hewan uji tikus jantan galur wistar adalah dosis $180 \mathrm{mg} / \mathrm{kg} \mathrm{BB}$.

\section{DAFTAR PUSTAKA}

1. World Health Organization. WHO Report: the global tobacco epidemic. Indonesia: World Health Organization; 2013.

2. Winarsi. Antioksidan Alami dan Radikal Bebas : Potensi dan Aplikasinya dalam Kesehatan. Yogyakarta : Kanisius; 2007. p. 138-281.

3. Lenzatti Manuella, Alan Lopes, Thiago S. Ferreira, Roberto Soares de Moura, Angela Resende, Luis Cristovao Porto, Samuel Santos Valenc. Mate Tea Ameliorates Emphysema In Cigarette Smoke-Exposed Mice. Experimental Lung Research. 2011 Juni-Oktober. ISSN : 0190-2148. 246-257.

4. Khairani M. Pengaruh Pemberian Wortel (Daucus carota) Terhadap Jumlah Sel Radang limfosit Submukosa Bronkiolus Tikus (Rattus norvegicus) Strain Wistar yang Dipapar Asap Rokok Kretek Subkronik. Skripsi. 2008. Universitas Brawijaya.

5. Kirana Ramaniya. Pengaruh Pemberian Teh Hijau (Cammelia sinensis) Terhadap Kerusakan Struktur Histologis Alveolus Paru Mencit yang Dipapar Asap Rokok. Skripsi. 2009. Fakultas Kedokteran Universitas Sebelas Maret Surakarta.

6. Galingging R. Y. Bawang Dayak (Eleutherine palmifolia) sebagai Tanaman Obat Multifungsi. Warta Penelitian dan Pengembangan Badan Penelitian dan Pengembangan Pertanian. 2009. 15 (3) : 10-16.

7. Nur A. M. Kapasitas Antioksidan Bawang Dayak (Eleutherine palmifolia) Dalam Bentuk Segar, Simplisia dan Keripik, pada Pelarut Nonpolar, Semipolar dan Polar. Skripsi. 2011. Institut Pertanian Bogor.

8. Dwiyana U. D. Penentuan Aktivitas Antibakteri Umbi Bawang Mekah (Eleutherine americana (L.) Merr ) terhadap Staphylococcus aureus dan Escherichia coli Beserta Profil Kromatografi Lapis Tipis. Skripsi. 2012. Fakultas Kedokteran Universitas Tanjungpura.

9. Ifesan B. O. T, Ibrahim D, Voravuthikunchai S. Antimicrobial Activity of Crude Ethanolic Extract from Eleutherine americana. J. Food- 
Agri and Env. 2010. Juli-Oktober. 8 (3-4) : 1233-1236.

10. Kuntorini E. M, Astuti M. D. Penentuan Aktivitas Antioksidan Ekstrak Etanol Bulbus Bawang Dayak (Eleutherine americana Merr.). J. Sains dan Terapan Kimia. 2010. Januari. 4(1) : 15-22.

11. Departemen Kesehatan Republik Indonesia. Parameter Standar Umum Ekstrak Tumbuhan Obat. Jakarta : Departemen Kesehatan Republik ; 2000. p. 5, 9-12.

12. Raaman N. Phytochemical Techniques. New Delhi: Jai Bharat Printing Press; 2006. p. 21-22.

13. Nurliani Anni, Santoso Heri Budi, Rusmiati. Efek Antioksidan Ekstrak Bulbus Bawang Dayak (Eleutherine palmifolia) pada Gambaran Histopatologis Paru-paru Tikus yang Dipapar Asap Rokok. Bioscintiae. 2012. 9(1): 60-69.

14. Hansel T.T, Barnes P.J. An Atlas of Chronic Obstructive Pulmonary Disease. London: Parthenon Publishing Group. 2004. p: 22-36

15. Voight R. 1995. Buku Pelajaran Teknologi Farmasi. Yogyakarta : UGM Press ; 1995. p. 561, 567-569, 577.

16. Gelfand EW. Pro: Mice Are a Good Model of Human Airway Disease. Am J Respir Crit Care Med. 2002 Juli. 166(1):5-8.

17. Aminah R. Pengembangan Model Kesehatan Koloni Tikus dan Mencit Percobaan Ditinjau dari Aspek Hematologis, Parasitologis, dan Histologis. Center for Research and Development of Disease Control. 2004.

18. Sihombing M, Raflizar. 2010. Status Gizi dan Fungsi Hati Mencit ( Galur Cbs- Swiss) Dan Tikus Putih (Galur Wistar) di Laboratorium Hewan Percobaan Puslitbang Biomedis Dan Farmasi. Media Litbang Kesehatan. 10:12-15

19. Bradbury steven. Reregistration Eligibility Decision (RED) Document For Nicotine. EPA. maret 2008. 40:11

20. Khabour, Alzoubi KH, Bani-Ahmad M, Dodin A, Eissenberg T, Shihadeh A. Acute exposure to waterpipe tobacco smoke induces changes in the oxidative and inflammatory markers in mouse lung. Inhal Toxicol. [Internet] 2012 Agustus [Dikutip Juli 2014] ; 24(10): 67-75.
21. H van der Vaart, D S Postma, W Timens, N H T Ten Hacken. Acute effects of cigarette smoke on inflammation and oxidative stress: a review. Thorax. 2004. 59:713-721

22. Halliwell, B, Whiteman, M. Measuring Reactive Species and Oxidative [Internet] Damage In Vivo And In Cell Culture: How Should You Do It and What Do Theresults Mean ?. $\mathrm{Br}$ J Pharmacol. 2004. 142, 231-255.

23. Supranto J. Teknik Sampling untuk Survei dan Eksperimen. Jakarta : PT Rineka Cipta ; 2000

24. Samuel Santos, Valenc A, Katia Da Hora, Paulo Castro, Vera Gonc, Alves Moraes, La'Is Carvalho, Lu'Is Crist 'Ov Ao De Moraes Sobrino Porto. Emphysema and Metalloelastase Expression in Mouse Lung Induced by Cigarette Smoke. Toxicologic Pathology. 2004 April. ISSN: 0192-6233. 32(3) : 351-356.

25. Kittel B, Ruehl-Fehlert C, Morawietz G, Klapwijk J, Elwell MR, Lenz B, O'Sullivan MG, Roth DR, Wadsworth PF. Revised guides for organ sampling and trimming in rats and mice Part 2. Exp Toxicol Pathol. 2010.55: 413-431.

26. Abdelmohsen Usama Ramadan,Matthias Szesny, Eman Maher Othman, Tanja Schirmeister, Stephanie Grond, Helga Stopper and Ute Hentschel. Antioxidant and Anti-Protease Activities of Diazepinomicin from the SpongeAssociated Micromonospora Strain RV115. Mar. Drugs. 2012. ISSN : 1660-3397. 10 : 2208-2221.

27. Lago João Henrique G, Alessandra C. ToledoArruda, Márcia Mernak, Kaidu H. Barrosa Milton A. Martins, Iolanda F. L. C. Tibério and Carla M. Prado. Structure-Activity Association of Flavonoids in Lung Diseases. Molecules. 2014. ISSN 1420-3049. $19: 3570-3595$.

28. NgTB, Cheung Randy CF, Ye X J, Wong Jack H and Ye X Y. Protease Inhibitors, Lectins, Antifungal Protein and Saponins in Soybean. www.intechopen.com. Diunduh tanggal 16 Agustus 2014.

29. Hodges LD, Kweifio-Okai G, Macrides TA. Antiprotease effect of anti-inflammatory lupeol esters. Mol Cell Biochem. 2003 Oct;252(12):97-101. 